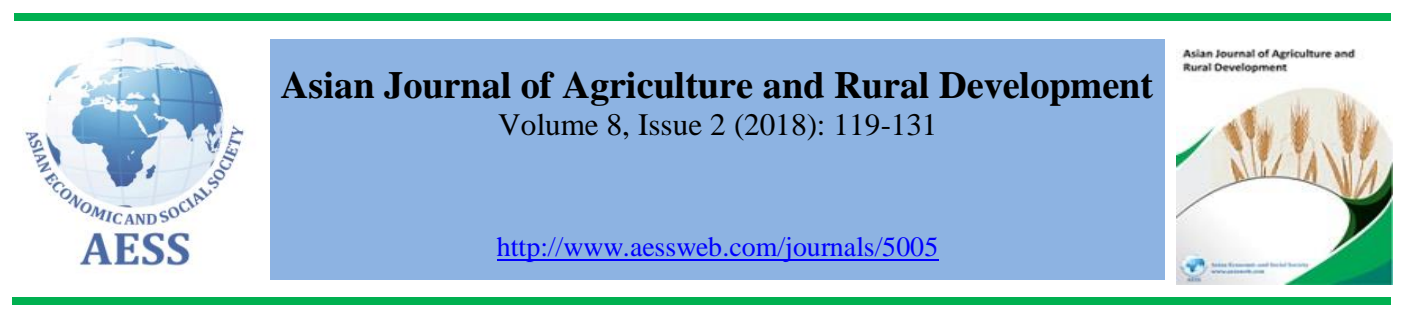

\title{
FACTORS THAT AFFECT FARMLAND CONVERSION IN CHINA AND INDONESIA
}

Lukman Adam a Center for Research, Expertise Agency of the House of Representatives of the Republic of Indonesia, and Doctoral

Li Xuefeng ${ }^{b}$

Jia Jin ${ }^{b}$
Candidate in Southwestern University of Finance and Economics, China

b Western China Center for Economic Research, Southwestern University of Finance and Economics, China

$\bowtie$ mada.kenn@gmail.com (Corresponding Author)

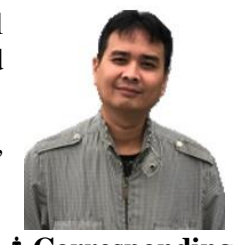

Corresponding

Author

\section{ARTICLE HISTORY:}

\section{ABSTRACT}

The first challenge in this century is to maintain or increase the

Received: 09-Oct-2018

Accepted: 10-Nov-2018

Online Available: $28-\mathrm{Nov}-$ 2018

\section{Keywords:}

Agriculture GDP,

Auto-Regressive

Distributive Lags (ARDL),

employment,

Urban population,

incentives

have a considerable population, have the same major food crops, and have been facing a problem with farmland conversion. The problem will be focused on the following issue whether factors are affecting farmland conversion in China and Indonesia. This research used the data from The World Bank in 1982 - 2014 and used Auto-Regressive Distributive Lags (ARDL) as the data analysis. In the short-run, investment and urban population are significant variables to affect the farmland conversion in China and Indonesia. The employment merely affects for farmland conversion in China, while the agriculture GDP and railways affect for Indonesia. In the long-run, employment and railways affect farmland conversion in China; however, the agriculture GDP, investment, and urban population are significant for Indonesia. Some policies which needed to prevent farmland conversion began stipulated zoning and spatial planning in central and local government, and incentives for the farmer.

\section{Contribution/ Originality}

This is first study on farmland conversion in China and Indonesia. There are few studies has been conducted about farmland conversion in China and Indonesia separately. However, farmland conversion is still infancy in the current literature insights. This article using slightly complete of the macro economy indicator.

DOI: 10.18488/journal.1005/2018.8.2/1005.2.119.131

ISSN (P): 2304-1455/ISSN (E):2224-4433

How to cite: Lukman Adam, Li Xuefeng and Jia Jin (2018). Factors that affect farmland conversion in China and Indonesia. Asian Journal of Agriculture and Rural Development, 8(10), 119-131.

(C) 2018 Asian Economic and Social Society. All rights reserved. 


\section{INTRODUCTION}

In 2030, the productivity of land should rise to fulfill food demand when forest area had no change. The productivity of labor has to rise in households if the target for poverty reduction and decreasing the poor ends to materialize (Timmer, 2014).

China and Indonesia are the important agricultural countries in Asia. China is the most population as well as the most food consumer country in the world. Whereas, Indonesia is the largest population in South-East Asia and the fourth most populous in the world. Indonesia and China have a vast population, 3.5\% Indonesia and $18.67 \%$ China population of the total world population. Thus, the challenge for Indonesia and China to supply $22 \%$ food for the world population, and the first challenge is to maintain the farmland. Similarly, Indonesia and China have the same major food crops. For Indonesia, currently, significant crops are rice, maize, soybeans, peanuts, cassava, and tuber, respectively. Meanwhile, for China, the staple foods are wheat, rice, soybean, maize, and tuber.

China and Indonesia have been facing problem-related farmland conversion simultaneously. The intensity of farmland conversion in developed countries much lower than developing countries, which is Indonesia and China are part of developing countries. For instance, farmland conversion in the Netherlands was 17 hectares per day during 1996-2000. On the conversely, China experienced 802 hectares of farmland converted per day in 2004 and Indonesia had 514 hectares of farmland converted per day during 2000-2002 (Tan et al., 2009). Many reasons why farmland conversion in developing countries increase continuously, for instance, in China and Indonesia, likely caused by housing and industry area demand, infrastructure development, as well as no proper spatial planning to protect farmland. Moreover, boom population has been pressuring to farmland as well as a change of government policy.

Pressure for farmland in China caused by the change of government and rural community insight. Rural communities have more opportunities livelihood, not only as a farmer who lived in rural but also works in the services sector which means move to the urban area. Moreover, infrastructure development extremely rapid in China since 1990. New construction of highways, airports, railways, and many more have been farmland change to another purpose.

In Tomohon, Indonesia, economic factors, landscape factors, and food security factors are ultimate factors that influence land conversion (Benu et al., 2013). In Karawang, Indonesia, land conversion in Indonesia was started in the 1980s when the Government became more open for investment (Irene, 2015). In Indonesia, the situation almost similar to China, much prominent rice production area had been changing by economic factors, mainly caused by investment.

Rural collectives are the owner all of the farmland in China. The households were given use right for the amount of the land for themselves in the 1980s. They have had the right to lease to others since 2008. Only 4 million had large-scale farming is $2 \%$ of the total, found by the recent census. In China, the change of farmland caused by change of government policy, because farmer no right for sold the land. In Indonesia, a farmer could sell the land if they have the right. Otherwise, if farmer get the land through the agrarian reform as stipulated by The Farmer Protection and Empowerment Act (Law Number 19/2013), they have no property right. This study focused on determining factors affecting farmland conversion in China and Indonesia. 


\section{METHOD OF THE STUDY}

\subsection{Theoretical framework}

Let $\mathrm{X}_{\mathrm{t}}$ be farmland derived from fixed stock of natural land reserves $(\mathrm{X})$ applying labor $\mathrm{L}_{\mathrm{t}}$. Thus, the land is treated as a natural capital form in this model and can write the motion equation for farmland as:

$$
X_{t+1=} X\left(1-\delta_{x}\right)+\psi, L_{t}, x, X_{0} \text { given, } X_{t} \leq \bar{X}
$$

The parameters $\psi>0$ are structurally estimated. According to Kuznets Theory, we develop the theory which agriculture GDP and employment are factors which increasing the farmland, whereas investment and urban population are factors which increasing the farmland conversion.

Capital in this study represented farmland and investment, whereas labor represented employment in agriculture (e.g., Hietel et al., 2007). Farmland conversion influenced by urban population (e.g., Azadi and Barati, 2013) and railways for goods transport (e.g., He et al., 2012) as a represent increasing development.

There are several human-behavior components that influence the farmland conversion (Hietel et al., 2007; Jinyan et al. 2010), including (1) demography such as population density and age structure, (2) employment and economy such as off-farm job alternative and working outside rural area, and (3) agricultural structure such as farmland coverage and production type. Change of land use throughout the nation dominated by urban and industrial land expansion. In recent years, transportation development, for instance new highways, railways, airports, seaports, and pipelines, has also been a major reason of land conversion, especially in the eastern and central regions ( $\mathrm{He}$ et al., 2012; Jiang and Zhang, 2016; Shi et al., 2016). In China, the most considerable reducing magnitude for arable land reached $371.83 \mathrm{~km}^{2}$; the increased using land came mainly from the conversion of arable land for economic development (Li et al., 2016).

\subsection{The benchmark models}

China and Indonesia are the biggest countries in each region that have been facing the same several challenges. Developing countries, having the enormous amount of population and mainland, as well as rapid development in the urban area, are the same characteristics between two countries. However, China and Indonesia have a different basis for farmland regulation. Some farmers in Indonesia are having farmland property right, otherwise, in China, farmers merely having farmland use right.

The variables used in this study were: amount of farmland conversion in Indonesia and China, V (hectares), agricultural gross domestic product, AGDP (constant 2010, million USD), investment, INV (million, USD), employment in agriculture, EMP (\%), urban population, UPOP (million), and railways for goods transported, RAI (million ton-km).

The farmland conversion measurement used the equation of land depreciation. The farmland conversion determined by calculating the farmland depreciation partially. The partial farmland depreciation explained as follow:

$V=L N D_{t}-L N D_{t-1}$

Where:

$\mathrm{V} \quad=\quad$ farmland conversion (hectares)

$\mathrm{LND}_{\mathrm{t}} \quad=\quad$ farmland area in year- $\mathrm{t}^{\text {th }}$ (hectares)

$\mathrm{LND}_{\mathrm{t}-1} \quad=\quad$ farmland area in the year before th (hectares) 
In this study, the dependent variable is the amount of farmland conversion (V), and the independent variables are the agricultural gross domestic product, (AGDP), investment (INV), employment in agriculture (EMP), urban population (UPOP), and railways for goods transported (RAI). To analyze the factors affected farmland conversion in China and Indonesia, we used the same model from both countries, the following model estimated is specified as:

$$
V_{t}=\beta_{0}+\beta_{1} A G D P_{t}+\beta_{2} I N V_{t}+\beta_{3} E M P_{t}+\beta_{4} U P O P_{t}+\beta_{5} R A I_{t}+\varepsilon_{t}
$$

In order getting the elasticity of coefficients and omit the outliers effect, the variables have to transform into the linear function. The form of a linear function of the equation becomes:

$$
L V_{t}=\beta_{0}+\beta_{1} L A G D P_{t}+\beta_{2} L I N V_{t}+\beta_{3} L E M P_{t}+\beta_{4} L U P O P_{t}+\beta_{5} L R A I_{t}+\varepsilon_{t}
$$

where: $L V_{t}=$ Logarithmic transformation of farmland conversion; $L A G D P_{\mathrm{t}}=$ Logarithmic transformation of AGDP; $L I N V_{\mathrm{t}}=$ Logarithmic transformation of investment; $L E M P_{\mathrm{t}}=$ Logarithmic transformation of employment in agriculture; $L U P O P_{\mathrm{t}}=$ Logarithmic transformation of urban population; and $L R A I_{\mathrm{t}}=$ Logarithmic transformation of railways for good transported. The error term $\left(\varepsilon_{t}\right)$ included the represents of the remove variables in the model and to capture all errors of the coefficient, parameter variations, and errors of the model. $\beta_{0}, \beta_{1}, \beta_{2}, \beta_{3}, \beta_{4}$, and $\beta_{5}$ are the elasticities to be estimated.

The first thing did with the time series data is testing for stationarity. The critical characteristic of stationarity time series, because we can study its behavior only for the time period under consideration. Each set of time series data will be for a particular episode (Gujarati and Porter, 2009). This article used the tests of Phillips-Perron (PP) and Augmented Dickey-Fuller (ADF) to test the stationarity and order of integration of the variables in critical values of $5 \%$.

We used the ARDL co-integration approach which built by Pesaran and Shin (1999) and Pesaran et al. (2001). There are three advantages in comparison with other previous and traditional cointegration methods. Firstly, the ARDL no need all the variables under observation to be integrated of the same order. Secondly, the ARDL test relatively more efficient. Lastly, unbiased estimates of the long-run model (Harris and Sollis, 2003). Based on the approach by Pesaran and Shin (1999), Pesaran et al., (2001), as well as Harris and Sollis (2003), the ARDL approach involves estimating the conditional error correction version of the ARDL model for variable under estimation. The $\operatorname{ARDL}\left(\mathrm{p}, \mathrm{q}_{1}, \mathrm{q}_{2}, \ldots, \mathrm{q}_{\mathrm{k}}\right)$ is given by the following equation:

$$
\alpha(\mathrm{L}, \mathrm{p}) y_{t}=\alpha_{0}+\sum_{i=1}^{k} \beta_{i}(L, q)+\lambda_{w t}+\varepsilon_{t}
$$

where:

$\alpha(\mathrm{L}, \mathrm{p})=1-\alpha_{1} L-\alpha_{2} L^{2}-\cdots-\alpha_{p} L_{p}$

$\beta_{i}\left(L, q_{i}\right)=\beta_{i 0}+\beta_{i 1} L+\beta_{i 2} L^{2}+\cdots+\beta_{i q_{i}} L^{q_{i}}$

$y_{t}$ is an independent variable, $\alpha$ is the constant term, $\mathrm{L}$ is the lag operator, for instance $L_{y t}=y_{t-1}$. Furthermore, $w_{t}$ is $\mathrm{s} \times 1$ vector of deterministic variables, for instance, intercept term, time trends, or exogenous variables with fixed lags. The long-run equation concerning intercept and time trend can be written as follows:

$$
\mathrm{y}=\alpha_{0}+\alpha_{t}+\sum_{i=1}^{k} \beta_{i} x_{i}+\gamma w_{t}+\eta_{t}, \text { where }: \alpha=\frac{\alpha_{0}}{\alpha}(L, p)
$$

Following the study from Owusu and Asumadu-Sarkodie (2017) and Ifa and Guetat (2018), this study employs the ARDL econometric approach due to its advantage over other econometric variables in small sample size. The ARDL model in this study as follows: 
$\Delta \mathrm{LV}_{\mathrm{t}}=\alpha+\delta_{1} \mathrm{LV}_{\mathrm{t}-1}+\delta_{2} \mathrm{LAGDP}_{\mathrm{t}-1}+\delta_{3} \mathrm{LINV}_{\mathrm{t}-1}+\delta_{4} \mathrm{EMP}_{\mathrm{t}-1}+\delta_{5} \mathrm{UPOP}_{\mathrm{t}-1}+\delta_{6} \mathrm{RAI}_{\mathrm{t}-1}+$ $\sum_{\mathrm{i}=1}^{\mathrm{p}} \beta_{1} \Delta \mathrm{LV}_{\mathrm{t}-1}+\sum_{\mathrm{i}=0}^{\mathrm{p}} \beta_{2} \Delta \mathrm{LAGDP}_{\mathrm{t}-1}+\sum_{\mathrm{i}=0}^{\mathrm{p}} \beta_{3} \Delta \mathrm{LINV}_{\mathrm{t}-1}+$

$\sum_{\mathrm{i}=0}^{\mathrm{p}} \beta_{4} \Delta \mathrm{LEMP}_{\mathrm{t}-1}+\sum_{\mathrm{i}=0}^{\mathrm{p}} \beta_{5} \Delta$ LUPOP $_{\mathrm{t}-1}+\sum_{\mathrm{i}=0}^{\mathrm{p}} \beta_{6} \Delta \mathrm{LRAI}_{\mathrm{t}-1}+\varepsilon_{\mathrm{t}}$

Where $\Delta$ indicates the first difference operator, $\alpha$ denotes the intercept, and $\rho$ denotes the lag order, and $\varepsilon_{\mathrm{t}}$ indicates the error term. The relationship between the variables are examined with F-test based on the null-hypothesis of no co-integration between $L V, L A G D P, L I N V, L E M P, L U P O P$ and $\operatorname{LRAI}\left(H_{0}: \delta_{1}=\delta_{2}=\delta_{3}=\delta_{4}=\delta_{5}=\delta_{6}=0\right)$, contrary to the alternative hypothesis of co-integration between $L V$, LAGDP, LINV, LEMP, LUPOP, and LRAI ( $\left.H_{1}: \delta_{1} \# \delta_{2} \# \delta_{3} \# \delta_{4} \# \delta_{5} \# \delta_{6} \# 0\right)$. The estimated F-statistic compared with the critical values of the lower and upper bounds.

\subsection{Data}

This study used annual time series secondary data. This data collected from the World Bank over the period 1982 - 2014. Another main data sources are the National Statistics Bureau in both countries, the Food and Agriculture Organization, and the Ministry of Agriculture.

\section{RESULT AND DISCUSSION}

The tests of Phillips-Perron and Augmented Dickey-Fuller (ADF) for test the stationarity and order of integration of the variables use critical threshold 5\%. Based on Table 1, almost all of the variables non-stationarity in level $\mathrm{I}(0)$, so we must check stationary at first and second difference. Furthermore, based on Table 2, in the first difference, there are a few variables have nonstationarity. However all variables are stationary in the second difference for both countries. Based on Table 2, the ARDL approach, therefore, can be made to test the hypothesis.

Table 1: Stationary at level I(0)

\begin{tabular}{lcccccc}
\hline PP Test & t-statistics & $\begin{array}{c}\text { China } \\
\text { Critical } \\
\text { values 5\% }\end{array}$ & Prob. & t-statistics & $\begin{array}{c}\text { Indonesia } \\
\text { Critical } \\
\text { values 5\% }\end{array}$ & Prob. \\
\hline V & -1.9241 & -2.9571 & 0.3175 & -1.1939 & -2.9571 & 0.6648 \\
AGDP & 4.8018 & -2.9571 & 1.0000 & 4.5054 & -2.9571 & 1.0000 \\
INV & 1.0291 & -2.9571 & 0.9959 & 0.6639 & -2.9571 & 0.9893 \\
EMP & 0.4628 & -2.9571 & 0.9826 & -3.7004 & -2.9571 & 0.0089 \\
UPOP & 8.5582 & -2.9571 & 1.0000 & -2.1003 & -2.9571 & 0.2458 \\
RAI & -0.7594 & -2.9571 & 0.8169 & -0.8298 & -2.9571 & 0.7968 \\
ADF Test & & & & & & \\
V & -1.5380 & -2.9571 & 0.5019 & -1.0048 & -2.9639 & 0.7385 \\
AGDP & 5.2340 & -2.9571 & 1.0000 & 4.9512 & -2.9571 & 1.0000 \\
INV & 3.6308 & -2.9918 & 1.0000 & 0.5750 & -2.9571 & 0.9867 \\
EMP & 1.4330 & -2.9677 & 0.9986 & -3.5001 & -2.9571 & 0.0145 \\
UPOP & -0.6995 & -2.9604 & 0.8324 & -1.7645 & -2.9604 & 0.3903 \\
RAI & -1.0484 & -2.9604 & 0.7230 & -0.8656 & -2.9571 & 0.7860 \\
\hline
\end{tabular}

Table 2: Stationary at level I(1) and I(2)

\begin{tabular}{lcccccc}
\hline $\begin{array}{l}\text { PP Test: First } \\
\text { difference }\end{array}$ & t-statistics & $\begin{array}{c}\text { China } \\
\text { Critical } \\
\text { values 5\% }\end{array}$ & Prob. & t-statistics & $\begin{array}{c}\text { Indonesia } \\
\text { Critical } \\
\text { values 5\% }\end{array}$ & Prob. \\
\hline V & -3.345 & -2.960 & 0.021 & -4.017 & -2.960 & 0.004 \\
AGDP & -2.756 & -2.960 & 0.076 & -2.244 & -2.960 & 0.196 \\
INV & -6.934 & -2.960 & 0.000 & -5.426 & -2.960 & 0.000 \\
EMP & -2.445 & -2.960 & 0.139 & -7.532 & -2.960 & 0.000 \\
UPOP & -1.663 & -2.960 & 0.440 & -2.320 & -2.960 & 0.172 \\
\hline
\end{tabular}




\begin{tabular}{lcccccc}
\hline RAI & -3.099 & -2.960 & 0.037 & -5.492 & -2.960 & 0.000 \\
PP Test: Second difference & & & & & \\
V & -6.73 & -2.96 & 0.00 & -11.87 & -2.96 & 0.00 \\
AGDP & -9.53 & -2.96 & 0.00 & -11.26 & -2.96 & 0.00 \\
INV & -10.68 & -2.96 & 0.00 & -11.57 & -2.96 & 0.00 \\
EMP & -6.17 & -2.96 & 0.00 & -23.28 & -2.96 & 0.00 \\
UPOP & -3.80 & -2.96 & 0.01 & -4.81 & -2.96 & 0.00 \\
RAI & -8.65 & -2.96 & 0.00 & -26.25 & -2.96 & 0.00 \\
ADF Test First Difference & & & & & \\
V & -3.139 & -2.960 & 0.034 & -4.900 & -2.964 & 0.000 \\
AGDP & -2.641 & -2.960 & -0.096 & -2.466 & -2.960 & 0.133 \\
INV & 0.158 & -2.976 & 0.964 & -5.412 & -2.960 & 0.000 \\
EMP & -3.575 & -2.968 & 0.013 & -7.524 & -2.960 & 0.000 \\
UPOP & -1.768 & -2.960 & 0.389 & -2.320 & -2.960 & 0.172 \\
RAI & -3.126 & -2.960 & 0.035 & -5.466 & -2.960 & 0.000 \\
ADF Test Second & Difference & & & & & \\
V & -5.276 & -2.968 & 0.000 & -7.389 & -2.968 & 0.000 \\
AGDP & -9.511 & -2.964 & 0.000 & -7.113 & -2.968 & 0.000 \\
INV & -7.114 & -2.976 & 0.000 & -8.340 & -2.968 & 0.000 \\
EMP & -6.279 & -2.964 & 0.000 & -6.486 & -2.964 & 0.000 \\
UPOP & -3.757 & -2.964 & 0.008 & -4.813 & -2.964 & 0.001 \\
RAI & -7.891 & -2.964 & 0.000 & -5.438 & -2.972 & 0.000 \\
\hline
\end{tabular}

The ARDL approach available the values of AGDP, INV, EMP, UPOP, and RAI, the ARDL approach available, not only in the past values but also in the current value. The numbers of delays for China and Indonesia are $(3,2,3,3,3,3)$ and $(2,1,3,2,3,1)$, for each variables respectively (Table 3).

Table 3: ARDL result

\begin{tabular}{|c|c|c|c|c|c|c|c|c|}
\hline \multirow{2}{*}{ Variables } & \multicolumn{4}{|c|}{ China: ARDL $(3,2,3,3,3,3)$} & \multicolumn{4}{|c|}{ Indonesia: ARDL $(2,1,3,2,3,1)$} \\
\hline & Coef. & Std.error & t-Stat. & Prob & Coef. & Std.error & t-Stat. & Prob \\
\hline$V(-1)$ & 0.3199 & 0.1949 & 1.6418 & 0.1446 & 0.7846 & 0.1601 & 4.9020 & 0.0004 \\
\hline$V(-2)$ & -0.0604 & 0.1348 & -0.4482 & 0.6675 & -0.5989 & 0.1272 & -4.7094 & 0.0005 \\
\hline$V(-3)$ & 0.1358 & 0.0871 & 1.5599 & 0.1628 & - & - & - & - \\
\hline AGDP & 0.0001 & 0.0001 & 1.4392 & 0.1933 & 0.0003 & 0.0001 & 2.5214 & 0.0268 \\
\hline $\operatorname{AGDP}(-1)$ & 0.0000 & 0.0001 & -0.0867 & 0.9333 & -0.0002 & 0.0001 & -1.5687 & 0.1427 \\
\hline $\operatorname{AGDP}(-2)$ & -0.0001 & 0.0001 & -2.0245 & 0.0826 & - & - & - & - \\
\hline INV & 0.0000 & 0.0000 & -2.7474 & 0.0286 & -0.0001 & 0.0001 & -2.7427 & 0.0178 \\
\hline $\operatorname{INV}(-1)$ & -0.0001 & 0.0000 & -4.1502 & 0.0043 & -0.0001 & 0.0001 & -1.9015 & 0.0815 \\
\hline INV(-2) & 0.0000 & 0.0000 & 1.5248 & 0.1711 & 0.0001 & 0.0001 & 2.1730 & 0.0505 \\
\hline $\operatorname{INV}(-3)$ & 0.0000 & 0.0000 & 2.0165 & 0.0836 & -0.0001 & 0.0000 & -1.7824 & 0.1000 \\
\hline EMP & 1.3873 & 0.4164 & 3.3319 & 0.0126 & -0.0216 & 0.0871 & -0.2484 & 0.8080 \\
\hline $\operatorname{EMP}(-1)$ & -1.1976 & 0.5953 & -2.0117 & 0.0841 & 0.0135 & 0.0132 & 1.0158 & 0.3298 \\
\hline $\operatorname{EMP}(-2)$ & -0.3570 & 0.4778 & -747175.00 & 0.4793 & 0.0349 & 0.0137 & 2.5543 & 0.0253 \\
\hline $\operatorname{EMP}(-3)$ & 1.0915 & 0.4622 & 2.3616 & 0.0502 & - & - & - & - \\
\hline UPOP & 1.3620 & 0.3972 & 3.4289 & 0.0110 & -1.5828 & 0.7079 & -2.2361 & 0.0451 \\
\hline UPOP(-1) & -3.1983 & 0.7383 & -4.3318 & 0.0034 & 2.0712 & 1.1940 & 1.7346 & 0.1084 \\
\hline UPOP(-2) & 2.3345 & 0.6051 & 3.8584 & 0.0062 & 0.9400 & 1.2392 & 0.7585 & 0.4628 \\
\hline UPOP(-3) & -0.4570 & 0.4243 & -1.0769 & 0.3172 & -2.0930 & 0.7912 & -2.6454 & 0.0214 \\
\hline RAI & -2.3266 & 2.6831 & -0.8671 & 0.4146 & 0.0009 & 0.0003 & 3.2361 & 0.0071 \\
\hline RAI(-1) & -6.2594 & 3.3151 & -1.8881 & 0.1010 & -0.0005 & 0.0002 & -2.1858 & 0.0071 \\
\hline RAI(-2) & -6.2515 & 3.7382 & -1.6723 & 0.1384 & - & - & - & - \\
\hline
\end{tabular}




\begin{tabular}{|c|c|c|c|c|c|c|c|c|}
\hline RAI(-3) & 27.1586 & 5.8635 & 4.6318 & 0.0024 & - & - & - & - \\
\hline $\mathrm{C}$ & 6.0137 & 28.6333 & 0.2100 & 0.8396 & 89.4343 & 24.8059 & 3.6054 & 0.0036 \\
\hline \multicolumn{9}{|c|}{ Model Criterion: } \\
\hline \multicolumn{2}{|c|}{ R-squared } & 0.9987 & & & 0.9830 & & & \\
\hline \multicolumn{2}{|c|}{ Adjusted R-squared } & 0.9945 & & & 0.9588 & & & \\
\hline \multicolumn{2}{|c|}{ F-statistic } & 239.9249 & & & 40.7257 & & & \\
\hline \multicolumn{2}{|c|}{$\operatorname{Prob}$ (F-statistic) } & 0.0000 & & & 0.0000 & & & \\
\hline
\end{tabular}

To verify the existence of the long-term co-integration relationship, we use the bounds test. The results of F-statistics confirm that there exist long-term co-integration relationship, both in China and Indonesia. The F-statistics values in China Model (14.91517) and Indonesia Model (11.70412) that is above the critical level threshold of $1 \%, 2.5 \%, 5 \%$, and $10 \%$, therefore, the hypothesis of $\mathrm{H} 0$ rejected, and subsequently, the hypothesis $\mathrm{H} 1$ is accepted, which indicates the existence of long-term co-integration relations.

Table 4: ARDL bounds test

\begin{tabular}{lcccc}
\multicolumn{1}{c}{ Test statistic } & Value & K & Value & Kina \\
\hline F-statistic & 14.91517 & 5 & 11.70412 & 5 \\
Critical value bounds & & & & \\
Significance & I0 Bound & I1 Bound & I0 Bound & I1 Bound \\
$10 \%$ & 2.26 & 3.35 & 2.26 & 3.35 \\
$5 \%$ & 2.62 & 3.79 & 2.62 & 3.79 \\
$2.5 \%$ & 2.96 & 4.18 & 2.96 & 4.18 \\
$1 \%$ & 3.41 & 4.68 & 3.41 & 4.68 \\
\hline
\end{tabular}

\subsection{In the short-run}

The notion of co-integration equation (CointEq (-1)) defines the delayed residue originating from long-term equilibrium equation. The negative sign of its estimated coefficient, as well as the statistical significance of China and Indonesia, confirm the presence of error correction. The coefficient of the co-integration equation explains the order in which the variable $\mathrm{V}$ (farmland conversion) will be mobilizing towards the long-term target. For our ARDL models, this coefficient is estimated to be 9.469895 for China and -0.814302 for Indonesia (Table 5).

Table 5: Short-run estimation and cointegrating form

\begin{tabular}{lcccccccc}
\hline \multirow{2}{*}{ Variables } & \multicolumn{3}{c}{ China: ARDL } & $\mathbf{3}, \mathbf{2}, \mathbf{3}, \mathbf{3}, \mathbf{3}, \mathbf{3})$ & \multicolumn{3}{c}{ Indonesia: ARDL(2, 1, 3, 2, 3, 1) } \\
& Coef. & $\begin{array}{c}\text { Std.erro } \\
\text { r }\end{array}$ & t-Stat. & Prob & Coef. & Std.error & t-Stat. & Prob \\
\hline D(V (-1)) & -10.562 & 0.1047 & -100.8926 & 0.0000 & 0.5989 & 0.1272 & 4.7094 & 0.0005 \\
D(V (-2)) & 0.2328 & 0.0871 & 2.6747 & 0.0318 & - & - & - & - \\
D(AGDP) & 0.0001 & 0.0001 & 1.4392 & 0.1933 & 0.0003 & 0.0001 & 2.5214 & 0.0268 \\
D(AGDP(-1)) & 0.0001 & 0.0001 & 2.0245 & 0.0826 & - & - & - & - \\
D(INV) & 0.0000 & 0.0000 & -2.7474 & 0.0286 & -0.0001 & 0.0001 & -2.7427 & 0.0178 \\
D(INV-1) & 0.0000 & 0.0000 & -1.5248 & 0.1711 & -0.0001 & 0.0001 & -2.1730 & 0.0505 \\
D(INV-2)) & 0.0000 & 0.0000 & -2.0165 & 0.0836 & 0.0001 & 0.0000 & 1.7824 & 0.1000 \\
D(EMP) & 1.3873 & 0.4164 & 3.3319 & 0.0126 & -0.0216 & 0.0871 & -0.2484 & 0.8080 \\
D(EMP-1) & 0.3570 & 0.4778 & 0.7472 & 0.4793 & -0.0349 & 0.0137 & -2.5543 & 0.0253 \\
D(EMP-2) & -1.0915 & 0.4622 & -2.3616 & 0.0502 & - & - & - & - \\
D(UPOP) & 1.3620 & 0.3972 & 3.4289 & 0.0110 & -1.5828 & 0.7079 & -2.2361 & 0.0451 \\
D(UPOP-1) & -2.3345 & 0.6051 & -3.8584 & 0.0062 & -0.9400 & 1.2392 & -0.7585 & 0.4628 \\
D(UPOP-2) & 0.4570 & 0.4243 & 1.0769 & 0.3172 & 2.0930 & 0.7912 & 2.6454 & 0.0214 \\
D(RAI) & 6.2515 & 3.7382 & 1.6723 & 0.1384 & 0.0009 & 0.0003 & 3.2361 & 0.0071 \\
\hline
\end{tabular}




\begin{tabular}{lllllcccc}
\hline $\mathrm{D}(\mathrm{RAI}-1)$ & -27.158 & 5.8635 & -4.6318 & 0.0024 & - & - & - & - \\
CointEq(-1) & 9.4699 & 0.1579 & 59.9820 & 0.0000 & -0.8143 & 0.1370 & -5.9440 & 0.0001 \\
\hline
\end{tabular}

For AGDP, the present and the delayed value of one year $(t-1)$ not statistically significant effect on the farmland conversion in China, on the contrast, the present value of AGDP in Indonesia has positive effect on the farmland conversion. This result in China agreed with the resulting study did by Zhang and Wang (2014) which said when economic growth in China reaches a certain level people pay more and more attention to the protection of land resources, farmland conversion rate would decreased.

Concerning the variable of INV, we note that the present value affects the farmland conversion negatively for both countries. About the EMP variable and UPOP variable, the present value of has quietly strong affects the China farmland conversion positively, in additional, the first delayed value $(\mathrm{t}-1)$ for UPOP variable have affect the China farmland conversion negatively. However, the EMP for the first delayed $(t-1)$ and UPOP variables in the present value and the second delayed $(t-2)$ significantly affect the Indonesia farmland conversion.

Finally, the RAI variable has a slightly strong negative role in stimulating farmland conversion in the first delayed value $(t-1)$ in China. This result getting a different result with study did by Wang and Sun (2016) which found that investment in transportation infrastructure affects rural development in China positively. Regarding cereal yield, a 1 percent increase in the road infrastructure (road length) leads to around 0.05 percent increase in cereal yield in the short-, and approximately 0.19 percent increase in the long-run. Our study got a different result because we use merely the data about railways. On the contrast, in the present value, RAI significant to affect farmland conversion in Indonesia.

Railways developed and used merely in Java, Indonesia. Other islands have railways from Dutch inheritance; however, people generally have been using the road or other transportation. Since 2010, three non-continuous railway networks in Sumatera, Kalimantan, and Sulawesi islands are being developed. The development of railways in Indonesia slower than China, because of the land acquisition, political will, and funding.

Chinese farmers never have the land; however, they do generally have long-term contractual rights to use it. When farms were first de-collectivized in 1978-1983, farm households typically got the right to farm a specified plot of land for one to three years. By the mid-1980s, household farm assignments generally extended to fifteen years, but these rights were insecure (Kroeber, 2016). The Government should determine the mechanism and regulation to organize this problem. The planning of a contract considers the future condition, including the internal and external factor, for instance, family size, local area planning, and market orientation. If the government changed the policy, the government should respect the contract with a farmer. The contract of farmland had better stipulated by the central government to avoid difference opinion of each local government.

\subsection{In the long-run}

In the long-run, for EMP and RAI variables significant with farmland conversion in China; however, in Indonesia, AGDP, INV, and UPOP variables are significant affect the farmland conversion. For more detail, Table 6 provides long-run coefficients from China and Indonesia. The performance of agriculture data in China presents the reason why EMP affect farmland conversion, 27.7 percent of the workforce employed in agriculture, 28.8 percent in industry and 43.5 percent in services in 2016. Since 2011, the majority of China's labor force has been employed in the service sector. 
Table 6: Long-run coefficients

\begin{tabular}{lcccccccc}
\hline \multirow{2}{*}{ Variables } & \multicolumn{4}{c}{ China } & \multicolumn{4}{c}{ Indonesia } \\
& Coef. & Std.error & t-Stat. & Prob & Coef. & Std.error & t-Stat. & Prob \\
\hline AGDP & 0.000 & 0.000 & 0.226 & 0.827 & 0.000 & 0.000 & 3.312 & 0.006 \\
INV & 0.000 & 0.000 & 1.018 & 0.343 & 0.000 & 0.000 & -3.524 & 0.004 \\
EMP & -0.098 & 0.039 & -2.532 & 0.039 & 0.033 & 0.106 & 0.309 & 0.763 \\
UPOP & -0.004 & 0.017 & -0.251 & 0.809 & -0.816 & 0.201 & -4.069 & 0.002 \\
RAI & -1.301 & 0.334 & -3.900 & 0.006 & 0.000 & 0.000 & 1.283 & 0.224 \\
C & -0.635 & 3.026 & -0.210 & 0.840 & 109.829 & 26.142 & 4.201 & 0.001 \\
\hline
\end{tabular}

The result presents AGDP affect farmland conversion in Indonesia positively. The result difference with another study which showed in Sleman, Yogyakarta Province, Indonesia, the internal factors which significantly influence the farmland conversion is the price of land and land location, while the variable GDP in the agricultural sector negatively (Harini et al., 2012).

In the future, the agricultural land conversion would continue unless there is no government reaction to reduce it (Azadi et al., 2011), and the policy should support by agricultural land policies (Makbul and Ratnaningtyas, 2017). Therefore, actions by the government become the important thing to reduce the farmland conversion.

Conversion of land caused by a lack of understanding by the community or government officials on spatial planning (Budhi et al., 2017). Difference insight between the Governments sector will happen because they must do some duties, for example as strategies to mitigate climate change, in the future we may see increasing land used for the production of biofuels, or for afforestation, instead of for food production (Lantz et al., 2017). In this side, the Central Government must have sharp vision, mission, and strategy to become synergy for all sector. For China and Indonesia, agriculture is the primary sector. The government must fulfil the food needs of the people. In the future, the biggest challenge is about the food because increasing the population, global warming, and many threatened to make fertile farmland decreased, and import will increased. Therefore, the Government must develop the perception is agriculture the most important things for the country.

We can see in the long-run, for the China model, based on the obtained results 1 unit decrease for RAI, decreasing in farmland conversion about 1.301082. In the long-run, science and technology development could increase agriculture productivity. The discovery of superior seeds, implementation the good of agricultural practices, and other supportive policies which related the agriculture technology are a determinant factor for agriculture in the future.

\subsection{Robustness check}

In the case of time series, the stability test or structural changes test, examine the stability of the estimated coefficients of the equation shows the presence of a structural change in the correlation (Ifa and Guetat, 2018). The CUSUM test then adapted to test the hypothesis of stability of the long-run relationship between farmland conversion and its determinants. For China and Indonesia, noted that the curves of the CUSUM and CUSUMSQ tests are within the limits of the confidence interval at the 5\% threshold. These results present the chosen model for estimating the relationships between the farmland conversion and determinants if the other variables are stable.

The CUSUM and CUSUMSQ tests indicated in graphic form Figure 1 and 2. For the CUSUM test, the blue line should between red upper and lower line for both countries. For CUSUMSQ test for China the blue line outside the red line from 1995 to 2009. We supposed because the Government changed the policy, for instance, in the 1990s, emerged "three rural areas" policy and this policy had effective on implementation after that period. The policies include agriculture, farmer, and rural and the adjustments for the policies finished in around 2000s. 

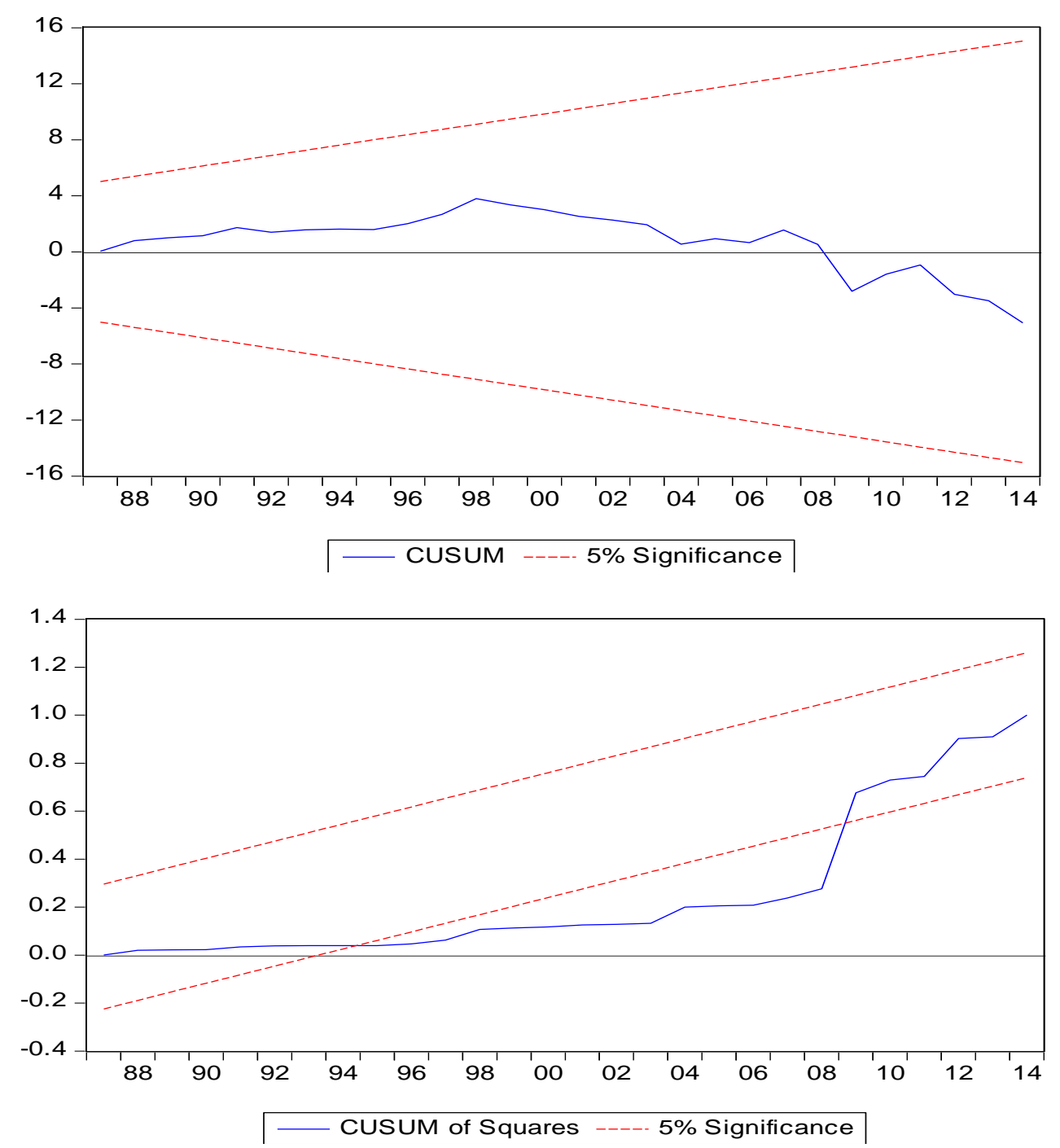

Figure 1: Cusum test of china model

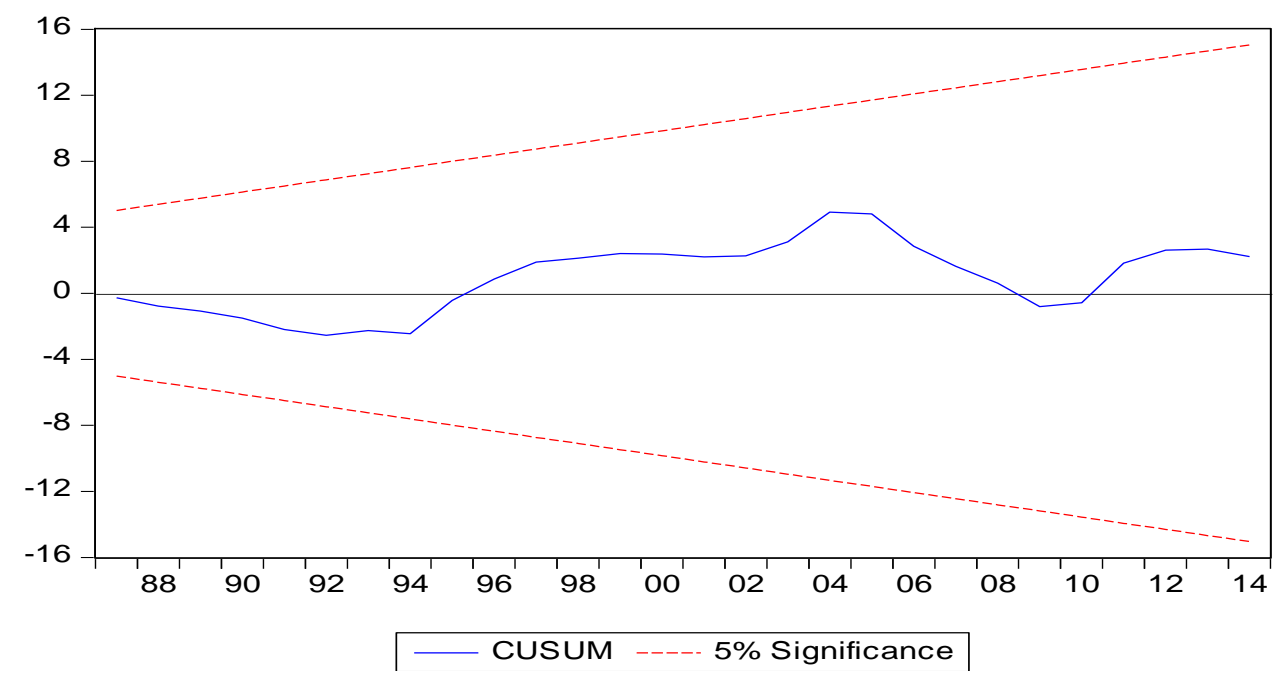




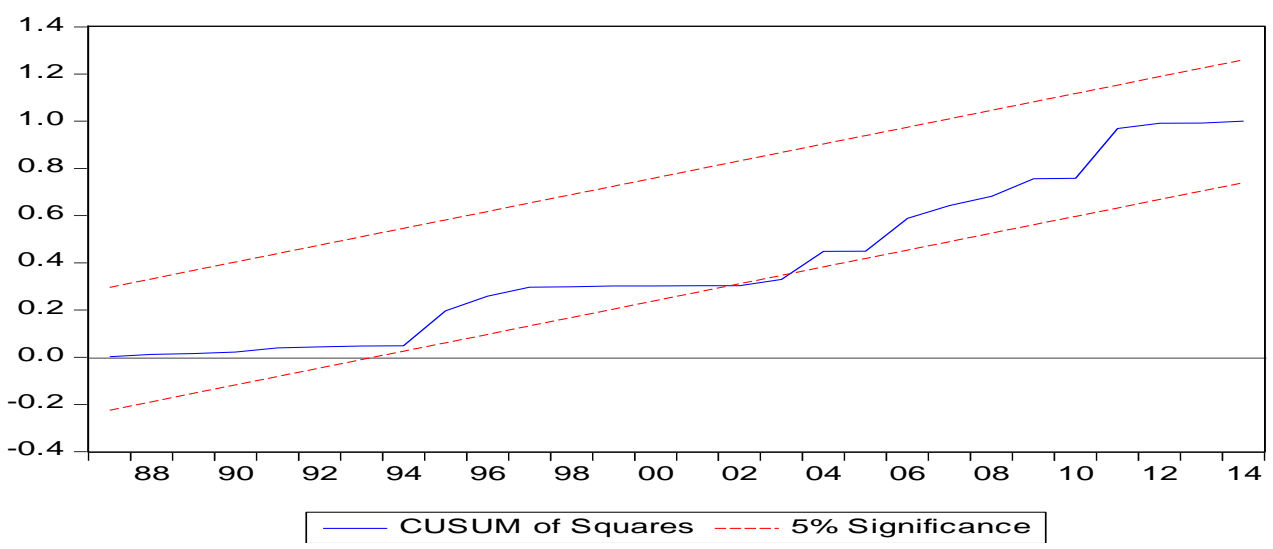

Figure 2: Cusum test of Indonesia model

Proper management and planning may restrict agricultural land conversion. The plan directs urban expansion to desire ways that protect fertile farmland through a stricter implementation of land use and spatial planning or even land conversion laws are needed (Azadi et al., 2011). Indonesia has been acting to prevent farmland conversion since 2009. The act gives an order to the district or municipal governments to make local regulation regarding the protection of farmland sustainability. Till the middle of 2017, just approximately 215 district/municipality governments from total amount 538 district/municipality had been regulation regarding the protection of farmland sustainability. The local government still thought for a short period rather than a future period, because for instance, a benefit for service, housing, and trade sector more significant than the agriculture sector in local government revenue. This condition makes farmland conversion increase continuously. Had better spatial planning policy became the central government policy rather than in local government. Moreover, needed incentives for local government who made this regulation.

In the farmer side, maintain farmland needs more effort, because many issues facing by farmer, for instance: (1) seed and fertilizer price increase faster rather than farmer purchasing power, (2) using water for agriculture purpose had a competition between another sector, (3) lack of agriculture facilities, (4) fluctuate selling price, and (5) tax treatment, especially land and building tax. For this issue, the Government should give the farmer incentives through subsidies and free land and building tax for farmers. Incentives were stimulated for farmer to maintain the farmland. Subsidies can provide for a farmer to get seed and fertilizer at a lower price. Another support can give farmer to obtain the best selling price which produced by the farmer; the Government, therefore, must stipulate the floor price when harvest season.

In another aspect, China has been facing the problem of water consumption which is ever increasing along with population growth, economic development, and a rising standard of living (Zhu et al., 2013). Besides, China is one of the countries suffering from the most severe soil and water loss in the world (Zhen, 2004). Ecosystem degradation obviously and makes environmental conservation agriculture tasks more difficult (Herman et al., 2017). Incentives not only refer to tax but also the infrastructure, include more develop the agricultural irrigation, because farmland facing soil and water loss.

\section{CONCLUDING REMARKS}

In the short-run, the AGDP and RAI not statistically significant variables affect farmland conversion in China, on the contrary, these variables are significant for Indonesia. INV and UPOP are significant variables to affect the farmland conversion in both countries. The EMP not 
statistically significant variable to affect the farmland conversion in Indonesia, however, significant variables for China.

In the long-run, the AGDP, INV, and UPOP not statistically significant variables affect farmland conversion in China, on the contrast, these variables are significant for Indonesia. Moreover, EMP and RAI are significant variables to affect farmland conversion in China, on the contrary, these variables are not statistically significant for Indonesia.

Some policies which needed to prevent farmland conversion began stipulated zoning and spatial planning in central and local government, and incentives for the farmer.

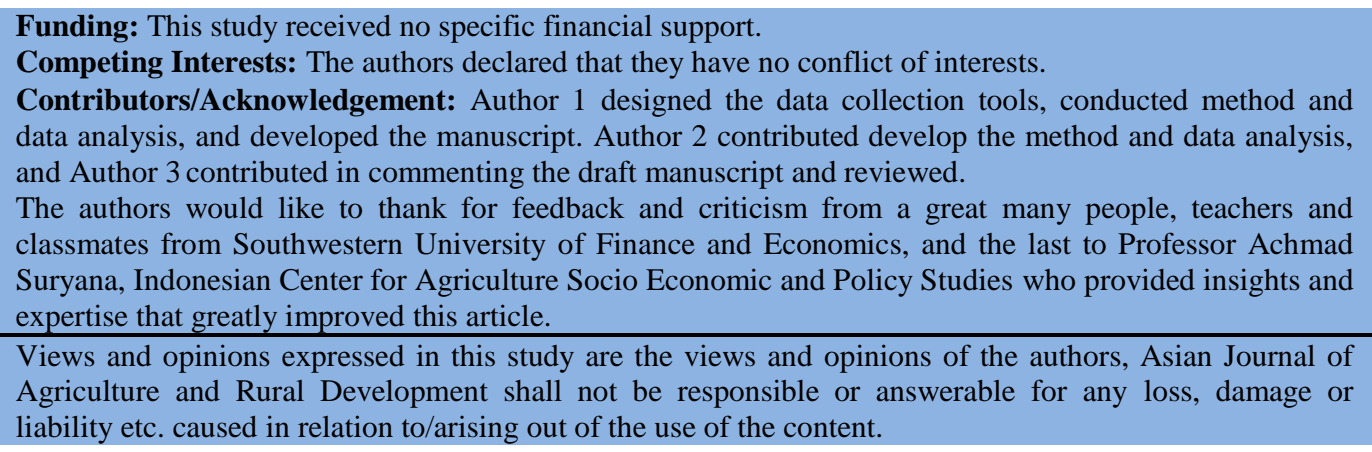

\section{References}

Azadi, H., \& Barati, A. A. (2013). Agricultural land conversion drivers in Northeast Iran. Working paper 36. United Kingdom: The Land Deal Politics Initiative. view at Google scholar / view at publisher

Azadi, H., Ho, P., \& Hasfiati, L. (2011). Agricultural land conversion drivers: a comparison between less developed, developing, and developed countries. Land Degradation and Development, 22, 596-604. view at Google scholar / view at publisher

Benu, N. M., Maryunani, S., \& Kindangen, P. (2013). Analysis of land conversion and its impacts and strategies in managing them in City of Tomohon, Indonesia. Asian Transactions on Basic and Applied Sciences (ATBAS), 03(02), 65-72. view at Google scholar

Budhi, M. K. S., Yasa, I. N. M., \& Darma, K. (2017). Impacts of development of population and conversion of agricultural land on food security (rice) in Bali, Indonesia. International Journal of Economics, Commerce and Management, 5(12), 634-643. view at Google scholar

Gujarati, D., \& Porter, D. (2009). Basic econometrics. New York: Mc Graw-Hill International Edition. view at Google scholar

Harini, R., Yunus, H., Kasto, S., \& Hartono, S. (2012). Agricultural land conversion: determinants and impact for food sufficiency in Sleman regency, Indonesian. Journal of Geography, 44(2), 120-133. view at Google scholar

Harris, R., \& Sollis, R. (2003). Applied time series modelling and forecasting. New York: Wiley.

He, C., Huang, Z., \& Wang, W. (2012). Land use changes and economic growth in China. Land Lines, Lincoln Institute of Land Policy. view at Google scholar

Herman, J., Zhao, Y., \& Jiang, B. (2017). Chinese experiences and lessons learnt in agricultural development since 1949. Asian Journal of Agriculture and Rural Development, 6(10), 201-209. view at Google scholar / view at publisher

Hietel, E., Waldhardt, R., \& Otte, A. (2007). Statistical modeling of land-cover changes based on key socio-economic indicators. Ecological Economics, 62(3-4), 496-507. view at Google scholar / view at publisher 
Ifa, A., \& Guetat, I. (2018). Does public expenditure on education promote Tunisian and Moroccan GDP per capita? ARDL approach. The Journal of Finance and Data Science, 20, 1-13. view at Google scholar / view at publisher

Irene, P. L. (2015). Farmland conversion in Karawang, Indonesia: discourse analysis. Thesis, Universiteit Gent. view at Google scholar

Jiang, L., \& Zhang, Y. (2016). Modelling urban expansion and agricultural land conversion in Henan Province, China: an integration of land use and socioeconomic data. Sustainability, 8, 920. view at Google scholar / view at publisher

Jinyan, Z., Nana, S., Shujin, H., \& Yingzhi, L. (2010). Factors and mechanism driving the land-use conversion in Jiangxi Province. Journal Geography Science, 20(4), 525-539. view at Google scholar / view at publisher

Kroeber, A. R. (2016). China's economy: what everyone needs to know. New York: Oxford University Press. view at Google scholar

Lantz, B., Dietz, S., \& Swanson, T. (2017). Global economic growth and agricultural land conversion under uncertain productivity improvements in agriculture. American Journal of Agriculture Economics, 100(2), 545-569. view at Google scholar / view at publisher

Li, X., Wang, Y., Li, J., \& Lei, B. (2016). Physical and socioeconomic driving forces of land-use and land-cover changes: a case study of Wuhan City, China. Discrete Dynamics in Nature and Society, Article ID 8061069. view at Google scholar / view at publisher

Makbul, Y., \& Ratnaningtyas, S. (2017). Analysis of the integration of rice and paddy prices in Indonesia using a vector error correction model. International Journal of Applied Business and Economic Research, 15(10), 209-225. view at Google scholar

Owusu, P. A., \& Asumadu-Sarkodie, S. (2017). Is there a causal effect between agricultural carbon dioxide emissions in Ghana? Environment Engineer Research, 22(1), 40-54. view at Google scholar / view at publisher

Pesaran, M., \& Shin, Y. (1999). An autoregressive distributed lag modeling approach to cointegration analysis. Cambridge: Cambridge University Press. view at Google scholar 1 view at publisher

Pesaran, M., Shin, Y., \& Smith, R. (2001). Bounds testing approaches to the analysis of level relationships. Journal of Applied Econometrics, 16(3), 289-326. view at Google scholar $/$ view at publisher

Shi, K., Chen, Y., Yu, B., Xu, T., Li, L., Huang, C., Liu, R., Chen, Z., \& Wu, J. (2016). Urban expansion and agricultural land loss in China: a multiscale perspective. Sustainability, 8 , 790. view at Google scholar / view at publisher

Tan, R., Beckmann, V., Berg, L., \& Qu, F. (2009). Governing farmland conversion: comparing China with The Netherlands and Germany. Land Use Policy, 26, 961-974. view at Google scholar

Timmer, C. P. (2014). Managing structural transformation: a political economy approach. Helsinki: United Nation University-World Institute for Development Economics Research (UNU-WIDER). view at Google scholar

Wang, Z., \& Sun, S. (2016). Transportation infrastructure and rural development in China. China Agricultural Economic Review, 8(3), 516 - 525. view at Google scholar

Zhang, L., \& Wang, Y. (2014). Study on the effects of economic growth to farmland conversion in China. Open Journal of Social Sciences, 2, 25-29. view at Google scholar

Zhen, L. (2004). Soil and water conservation in China. Paper presented at the $9^{\text {th }}$ International Symposium on River Sedimentation, Hubei, China, October, 18-21. view at Google scholar

Zhu, X., Li, Y., Li, M., Pan, Y., \& Shi, P. (2013). Agricultural irrigation in China. Journal of Soil and Water Conservation, 68 (6), 147A-154A. view at Google scholar 